\title{
The influence of current ratio, debt to equity ratio, and return on assets on dividend payout ratio
}

\author{
Widya Shabrina $^{1 *}$, Niki Hadian ${ }^{2}$ \\ Accounting Department, Faculty of Economics and Business, University of Widyatama ${ }^{1,2}$ \\ $\underline{\text { widya.shabrina@widyatama.ac.id }}^{{ }^{*}}$, niki.hadian@widyatama.ac.id ${ }^{2}$
}

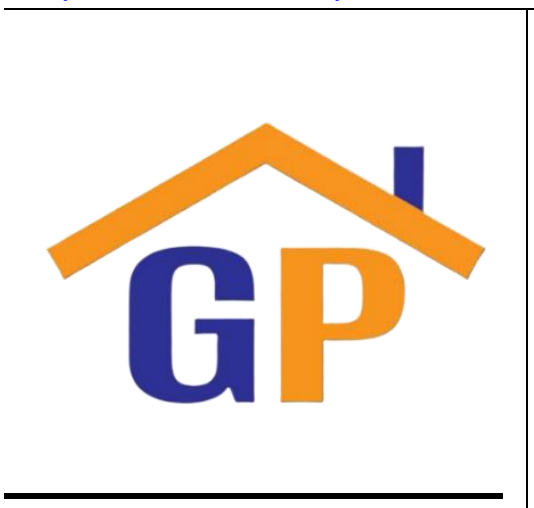

Article History

Received on 26 August 2020

$1^{\text {st }}$ Revision on 21 September 2020

$2^{\text {nd }}$ Revision on 30 September 2020

Accepted on 1 October 2020

\begin{abstract}
Purpose: This study aimed to determine whether the current ratio, debt to equity ratio, and return on assets affected the dividend payout ratio of mining companies listed on the Indonesia Stock Exchange for the 2016-2018 period.

Research Methodology: The research method used in this study was an explanatory method. The sampling technique used in this study was non-probability sampling with a purposive sampling technique so that the total sample size was 34 mining companies listed on the Indonesia Stock Exchange for the period 2016-2018. The analysis method used in this research was panel data regression analysis using Eviews 9.
\end{abstract}

Results: The results showed that the current ratio, debt to equity ratio, and return on assets affected the dividend payout ratio. In addition, the research results also showed that the magnitude of the influence of the current ratio, debt to equity ratio, and return on assets in contributing to the dividend payout ratio was $51.5 \%$.

Limitations: The study was limited to only a few factors, namely the current ratio, debt to equity ratio, and return on assets to the dividend payout ratio.

Contribution: This research is expected to be of benefit to the company in determining the policy of dividend distribution from several financial performance factors including current ratio, debt to equity ratio, and return on assets.

Keywords: Current Ratio, Debt to Equity Ratio, Return on Assets, and Dividend Payout Ratio

How to Cite: Shabrina, W, and Hadian, N. (2021). The Influence of Current Ratio, Debt to Equity Ratio, and Return on Assets on Dividend Payout Ratio. International Journal of Financial, Accounting and Management, 3(3), 193-204.

\section{Introduction}

Capital market is an assembly between parties who have more funds and parties who need funds by trading securities (Tandelilin, 2017). Capital market can also be interpreted as a place or means of meeting between supply and demand for long-term financial instruments, generally more than 1 (one) year (Samsul, 2015). In general, investors have the main objective of investing their capital in companies, which is to seek income or return on investment, both income of dividend yield and income of differences between the selling price of shares and the purchase price, which is called capital gain (Wicaksana, 2012). Investors tend to prefer dividends compared to capital gains because dividends promise something more certain (Ibrahim, 2019). Dividends are the distribution of company income which is the right of shareholders in the form of cash, assets, or other forms. The proportion of dividends paid to shareholders depends on the ability of the company to generate profits as well as the dividend policy established by the company concerned. According to Atmaja (2008), DPR came from EAT which was divided in the form of dividends and partially reinvested. This means that management must make a decision about the amount of EAT to be distributed as dividends. 
Several cases show that companies that do not always experience an increase in profits will also pay high dividends. On the other hand, there are even companies that do not pay dividends even though the company is making a profit. It includes PT. Bumi Resources Tbk (BUMI), PT Aneka Tambang Tbk (ANTM), and PT. Vale Indonesia Tbk (INCO) which decided not to distribute dividends even though the company made a profit. Supposedly with the profit earned by PT. Bumi Resources Tbk (BUMI), PT. Aneka Tambang Tbk (ANTAM), and PT. Vale Indonesia Tbk (INCO), the companies can distribute dividends. For shareholders, dividends are a form of return on their investment. Meanwhile, for creditors, dividend distribution is a positive signal that the company has the ability to pay interest and principal on the loan. Dividend distribution policy is affected by several financial performance factors including CR, DER, and ROA.

$\mathrm{CR}$ is a ratio that measures the ability of a company to pay the short-term obligations whether debt that is due immediately when they are collected as a whole. Otherwise, how many current assets are on hand to cover short-term liability that is due as possible. CR is able to be considered as a form of measuring the level of safety (margin of safety) of the companies (Kasmir, 2019). A fast drop in the CR sometimes signals trouble. Companies that exacerbate their debts by delaying payment of their bills will experience an enhancement in current liabilities and a lowering in the CR (Ibrahim, 2019). CR describes the ability of a company to pay the short-term debt. The higher ability of companies to pay the short-term debt shows that the availability of current assets owned by the firm is quite high so that the company tends to have the ability to distribute dividends to shareholders.

DER is the ratio used to quantify how big of debt to equity. DER is counted as the result outcome among total debt and equity. DER is used to determine the ratio among the number of funds provided by creditors and the number of funds originating from the companies owners. Otherwise, DER is used to find out how much of each rupiah of capital is used to debt collateral. The higher the DER, the smaller the owner's capital that can be used as debt collateral (Hery, 2018). DER is also an important factor that needs to be focused on influencing the company's dividend policy. DER describes the height of debt owed by the company. The higher debt owed by companies, then the companies have an obligation to fulfill the company's debt first. This occurs due to the company's financial condition, thus affecting the low dividend distribution policy to shareholders.

ROA is a ratio indicating how big the ante of assets making net income. Therefore, ROA measures how much net profit is going to be produced of each rupiah of funds that inveterate total assets. ROA is counted by dividing net income to total assets. The higher the ROA, the more increase the amount net profit produced from each rupiah of a fund invested total assets. Otherwise, lower the ROA means lower the amount of net profit generated from each rupiah of funds that is embedded in total assets (Hery, 2018). Profit is also often used as an indicator of the number of dividends that the company will distribute. ROA describes the ability of a company to earn profits. The higher profit of companies gets, the higher the dividend distribution policy will be to shareholders.

\section{Literature Review and Hypothesis Development Financial statements}

Financial Accounting Standard Statement No. 1 Paragraph 9 of the Financial Accounting Standards (2018) states that financial statements are a structured presentation of the financial performance and financial position of an entity. The purpose of financial statements is to prepare information about the entity's financial performance, financial position, and cash flows that is useful for most users of financial statements in making economic decisions. The financial statements represent the results of the management accounts for the use of resources entrusted to them.

\section{Financial Ratio Analysis}

The analysis ratio is carried out by connecting various estimations in financial statements in form of financial statements. This financial analysis ratio can reveal important relationships between estimated financial statements and be used to evaluate the financial condition and performance of the company (Hery, 2018). Financial ratio analysis is a method that calculates and interprets financial ratios to assess 
the show and status of a company (Sjahrial, 2009). The objective of financial ratio analysis is that the comparisons made to items in the financial statements constitute a logical comparison, using certain recognized measures as guidelines for decision making.

According to Sutrisno (2012) the grouping of financial ratios according to the objectives is divided into 5 types, namely:

1. The liquidity ratio is used to quantify the ability of the company to pay its short-term debts.

2. The leverage ratio is used to quantify the extent to which the company's assets are financed by debt.

3. The activity ratio is the ratio used to quantify the effectiveness of the company in utilizing its sources of funds.

4. A profitability ratio is a ratio used to quantify the effectiveness of the company in getting profits.

5. Appraisal ratio is used to measure management's capability to create market value in order to exceed the cost of capital.

\section{Current Ratio (CR)}

$\mathrm{CR}$ is a ratio that measures the ability of the companies to pay the short-term obligations or debt that is due immediately when they are collected on the whole. Therefore, it indicates the current assets available to cover the short-term liability that is the due date. CR is able to be considered a form of measuring the level of safety (margin of safety) of the companies (Kasmir, 2019). CR is measured using the following formula:

$$
C R=\frac{\text { Current Assets }}{\text { Current Liabilities }}
$$

\section{Debt to Equity Ratio (DER)}

DER is a ratio used to quantify the proportion of debt to equity. DER is counted as the quotient among total debt and equity. DER is used to determine the ratio between the number of funds provided by creditors and the number of funds originating from the companies owners. Therefore, this is ratio serves to find out how much each rupiah of capital is used as debt collateral. The higher the DER, the smaller the owner's equity is used debt collateral (Hery, 2018). DER is measured using the following formula:

\section{Return on Asset (ROA)}

$$
D E R=\frac{\text { Total Liabilities }}{\text { Total Equity }}
$$

ROA is a ratio indicating how big the ante of assets making net income. Therefore, ROA measures how much net profit is going to be produced of each rupiah of funds that inveterate total assets. ROA is counted by dividing net income to total assets. The higher the ROA, the more increase the amount net profit produced from each rupiah of a fund invested total assets. Otherwise, lower the ROA means lower the amount of net profit to be produced from each rupiah of funds that is embedded in total assets (Hery, 2018). ROA is measured using the following formula:

$$
\mathrm{ROA}=\frac{\text { Earning After Tax }}{\text { Total Aset }}
$$

\section{Dividend Payout Ratio (DPR)}

Dividends are part of profits paid by the company to its stockholders (Sutrisno, 2012). According to Brigham \& Houston (2011), several types of dividends paid by companies are:

1. Cash Dividend

The cash dividend is cash paid in cash. In general, cash dividends are preferred shareholders, and more often used companies appeal to other types of dividends.

2. Stock Dividend

Stock dividends are dividends paid in shares, not in cash. The payment of stock dividends must also be advised that there is an available profit or surplus, with the dividend payment of 
these shares, the number of shares outstanding will increase, but the payment of stock dividends will not change the liquidity position because what is paid by the company is part of the company's cash flow.

3. Property Dividend

Property dividends are dividends paid in the form of configuration (assets besides cash). This distributed property dividend is an item that can be divided or homogeneous parts and its distribution to shareholders will not interfere with the continuity of the company.

4. Dividend Script

Dividend script is the dividend paid in the form of a debt promise script. The company will pay a certain amount at a certain time as stated in the script. Payment in this form will cause the company to have a short-term debt to the script holder.

5. Liquidating Dividend

A liquidating dividend is a dividend paid based on a reduction in the companies capital, not based on profits earned by the companies.

Dividend policy is a decision whether the profits earned by the companies are going to be distributed to stockholders if dividends or is going to be retained in form of retained earnings for future investment financing (Sartono, 2001). According to Atmaja (2008), DPR came from EAT which is divided in the form of dividends and partially reinvested. This means that management must make a decision about the amount of EAT to be distributed as dividends. DPR is measured using the following formula:

$$
\text { DPR }=\frac{\text { Dividends Distributed }}{\text { Earning After Tax }}
$$

\section{The Effect of Current Ratio on Dividend Payout Ratio}

$\mathrm{CR}$ is a ratio that measures the ability of a company to pay the short-term obligations whether a debt is due immediately when they are collected as a whole. Otherwise, how many current assets are on hand to cover the short-term liability that is due date. The CR can also be considered a form of measuring the level of safety (margin of safety) of companies (Hery, 2018). A low CR indicates that the company lacks the capital to pay off debt. However, if the measurement results of the CR are high, it is not necessarily that the companies are in nice condition. The higher CR, the more secure the company's debts to creditors. For creditors, the higher the CR the better, but for certain companies, it can mean different things. If this ratio is high, it means that the company has excessive current assets or something is not optimal (Ibrahim, 2019). Research conducted by Ibrahim (2019) and Adhyvian et al (2019) stated that CR affected the DPR. Meanwhile, research conducted by Purba et al (2019) and Sarmo et al (2019) stated that the CR had no effect on the DPR. From the description above, the hypothesis that was formed as follows:

H1: CR affects DPR.

\section{The Effect of Debt to Equity Ratio on Dividend Payout Ratio}

DER is a ratio be used to quantify the proportion of debt to equity. DER is counted as the quotient among total debt and equity. DER is used to determine the ratio among the number of funds prepared by creditors and the number of funds originating from the companies owners. Therefore, DER attends to find out how much each rupiah of equity is used as debt collateral. The higher the DER, the smaller the owner's capital that can be used as debt collateral (Hery, 2018). If the DER is higher, the risk faced by investors will be even greater. A high DER indicates that the company's dependence is also high. This is due to the large amount of debt used by the company to finance the company and the value of the existing debt will be borne by investors. Therefore, investors prefer companies that have a small DER, because the smaller the DER owned by the company, the less risk that will be borne by investors. Companies have a large DER grade, then the dividends distributed are getting smaller, this is because the profits generated by the company are used to pay debts that have been used by the company, and vice versa (Adhyvian et al, 2019). Research conducted by Ibrahim (2019) and Mufidah (2018) showed that the DER affected DPR. Meanwhile, research conducted by Purba et al (2019), Mufidah and 
Khorunnisa (2016) stated that DER had no effect on DPR. From on description above, the hypothesis that is formed as follows:

H2: DER affects the DPR.

\section{The Effect of Return on Assets on Dividend Payout Ratio}

ROA is a ratio that seems how big the ante of assets in making net income. Therefore, ROA is used to quantify how much net profit is going to be produced each rupiah of funds is inveterate total assets. ROA is counted by dividing net income to total assets. The higher ROA, the more increase the amount of net profit produced from each rupiah funds invested total assets. Otherwise, the lower ROA means lower the net profit produced from each rupiah of funds inveterate total assets (Hery, 2018). A positive ROA that seems of the total assets be used to operate, the firm can provide profits for the companies. Otherwise, if negative ROA that seems of the total assets be used, the firm gets a loss, and the greater the ratio the better because the company is considered capable of using its assets effectively to generate profits (Ibrahim, 2019). Research conducted by Ibrahim (2019), Mufidah (2018), Mufidah and Khorunnisa (2016) stated that ROA affected the DPR. Meanwhile, research conducted by (Trilestari \& Kusuma, 2016) stated that ROA had no effect on the DPR. Based on the description above, the hypothesis that is formed is as follows:

H3: ROA affects the DPR.

The following figure presents frame of mind chart as a form of the researcher's thought flow, which is as follows:

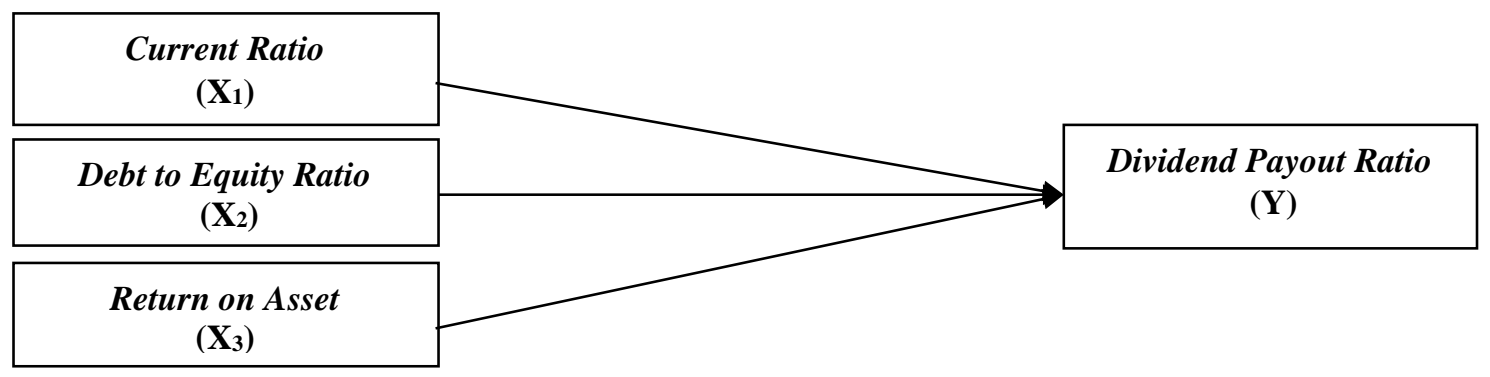

Figure 1. Framework

\section{Research Methodology}

The kind of research was quantitative research. The research method is used in this research verification. The population in this study was 44 mining companies listed on the BEI for the 2016-2018 period. The technique sampling used in this study was non-probability sampling with a purposive sampling method so that the total sample size was 34 companies. Types and sources of data be used in the study were secondary data. The data collection method is used was literature studies and document study in form of company financial reports. The independent variables studied were CR, DER, and ROA, while the dependent variable in this study was DPR. The analysis data be used in this research was data panel regression analysis. The significant level used was 5\%. The program is used in analyzing data used Eviews 9.

\section{Results and Discussion Research Result}

Description Regarding Current Ratio

The results showed that in 2016, the average value of the CR was 186.80. In 2017, the average value of the CR has increased to 203.73. In 2018, the average value of CR increased to 476.85. From the graph above, it can be seen that the average grade of the CR of mining the companies listed on the BEI for the 2016-2018 period showed an increase, meaning that the ability of the company to meet short-term obligations whether the debt was maximal. The high value of CR illustrates the high ability of companies to meet the short-term liabilities or debt from current assets owned by the company. A low $\mathrm{CR}$ value illustrates that the companies' low ability to meet the short-term liabilities whether debt from 
CR owned by companies. The increase in the grade value of CR can be caused by the low amount of the company's current assets.

\section{Description Regarding Debt to Equity Ratio}

The results showed that in 2016, the average DER was 1.23. In 2017, the average DER increased to 1.64. In 2018, the average DER increased to 2.23. From the graph above, it can be seen that the average grade of the DER of mining the companies listed on the BEI for the 2016-2018 period shows an increase, meaning that the amount of debt the company-owned tended to increase every year. The high DER illustrates the level of debt the company has. A low DER illustrates the small level of debt the company has. The increase in the value of the DER was due to the increase in the amount of corporate debt and the high corporate debt policy. The decline in the value of the DER was due to the decrease in the company's debt and the low and high debt policy of the company.

\section{Description Regarding Return on Assets}

The results showed that in 2016, the average value of ROA was 0.60. In 2017, the average value of ROA has increased to 6.75. In 2018, the average value of ROA increased to 1.46. From the graph above, it can be seen that the average grade of ROA in mining the companies listed on the BEI for the 20162018 period showed a fluctuating value, meaning that the ability of the company to earn profits in one period was still not optimal. The high ROA value illustrates that the companies' high ability to manage the company's assets to generate profits. The low ROA illustrates the company's low ability to manage companies' assets to produce labs. The increase in the grade of ROA is due to the high effectiveness and efficiency of management in managing company assets, increased company sales, low company operating costs, and other factors. The decline in the value of ROA was caused by the low effectiveness and efficiency of management in managing company assets, decreased sales of the company, high operating costs of the company, and other factors.

\section{Description Regarding Dividend Payout Ratio}

The results showed that in 2016, the average DPR was 186.80. In 2017, the average value of the DPR has increased to 203.73. In 2018, the average DPR increased to 476.85. From the graph above, it can seem the average grade of the DPR of mining the companies listed on the BEI for the period 2016-2018 showed a fluctuating value, meaning that the number of dividends distributed to stockholders in the company tended to be erratic. A high DPR illustrates the high dividends distributed to stockholders in the companies. A low DPR illustrates the low dividend distributed to shareholders in the company. The increase in the value of the DPR was due to the existence of a company management policy (GMS) related to dividend distribution and the low retained earnings policy. The decrease in the value of the DPR was caused by the need for capital for the company's operations, thereby increasing the existence of a retained earnings policy and reducing the dividend distribution policy.

Table 1. Descriptive Statistical Test

\begin{tabular}{|l|c|c|c|c|}
\hline & CR & DER & \multicolumn{1}{c|}{ ROA } & DPR \\
\hline Mean & 289.1246 & 1.700686 & 2.934706 & 0.240000 \\
\hline Maximum & 11131.26 & 34.06000 & 39.41000 & 3.020000 \\
\hline Minimum & 1.460000 & -2.110000 & -53.25000 & -0.240000 \\
\hline Std. Dev. & 1096.796 & 3.659927 & 11.00982 & 0.453567 \\
\hline Skewness & 9.617271 & 7.153357 & -0.458105 & 3.056393 \\
\hline Kurtosis & 95.49037 & 61.84446 & 11.12051 & 15.98777 \\
\hline
\end{tabular}

Source: Output Eviews 9

Based on Table 1 above, it shows the results of descriptive statistical testing, which are as follows:

1. The variable CR seems an average grade of 289.1246. The maximum grade of 11131.26 is at PT Perdana Karya Perkasa Tbk in 2018. The minimum value of 1.460000 is at PT Bumi Resources Minerals Tbk in 2016. The standard deviation value is 1096.796. The skewness value is 9.617271. The kurtosis value is 95.49037 . 
2. DER variable seems an average grade of 1.700686. The maximum grade of 34.06000 is at PT Atlas Resources Tbk in 2018. The minimum value of -2.110000 is at PT Bumi Resources Tbk in 2016. The standard deviation value is 3.659927. The skewness value is 7.153357. The value of kurtosis is 61.84446 .

3. The ROA variable seems an average grade of 2.934706. The maximum grade of 39.41000 is in PT Baramulti Suksessarana Tbk in 2017. The minimum value of -53.25000 is in the PPT Bumi Resources Minerals Tbk in 2016. The standard deviation value is 11.00982 . The skewness value is -0.458105 . Kurtosis value is 11.12051 .

4. The DPR variable seems an average grade of 0.240000 . The maximum grade of 3.020000 is at PT Bukit Asam Tbk in 2016. The minimum value of -0.240000 is at PT Medco Energi Internasional Tbk in 2018. The standard deviation value is 0.453567. Skewness value is 3.056393. The kurtosis value is 15.98777 .

Table. 2 Chow Test

Source: Output Eviews 9

\begin{tabular}{|c|c|c|}
\hline Information & Probability Value & Result \\
\hline Cross-section Chi-square & $0.0000<0.05$ & $\mathrm{H}_{\mathrm{o}}$ is Rejected \\
\hline
\end{tabular}

From Table 2 above, it seems that the chi-square cross-section probability grade of 0.0000 is smaller than the probability grade of $0.05(0.0000<0.05)$, so the results of the chow test reject Ho. This means that the model rejects the common effect model and follows the fixed effect model.

Table 3. Hausman Test

\begin{tabular}{|c|c|c|}
\hline Information & Probability Value & Result \\
\hline Cross-section random & $0.2006>0.05$ & $\mathrm{H}_{\mathrm{o}}$ is accepted \\
\hline
\end{tabular}

Source: Output Eviews 9

Based on Table 3 above, it shows that the chi-square random cross-section probability value of 0.2006 is greater than the probability value of $0.05(0.2006>0.05)$, thus the result of the Hausman test accepts Ho. This means that the model rejects the fixed-effect model and follows the random effect model.

Table 4. Lagrange Multiplier Test

\begin{tabular}{|c|c|c|}
\hline Information & Probability Value & Result \\
\hline Cross-section Breusch-Pagan & $0.0056<0.05$ & $\mathrm{H}_{\mathrm{o}}$ is rejected \\
\hline
\end{tabular}

Source: Output Eviews 9

From Table 4 above, it seems that the chi-square random cross-section grade of 0.0056 is smaller than the probability grade of $0.05(0.0056<0.05)$, then the Lagrange multiplier test results reject Ho. This means that the model rejects the common effect model and follows the random effect model. From the three tests for selecting the panel data model, it shows that the right model to use is the random effect model. 


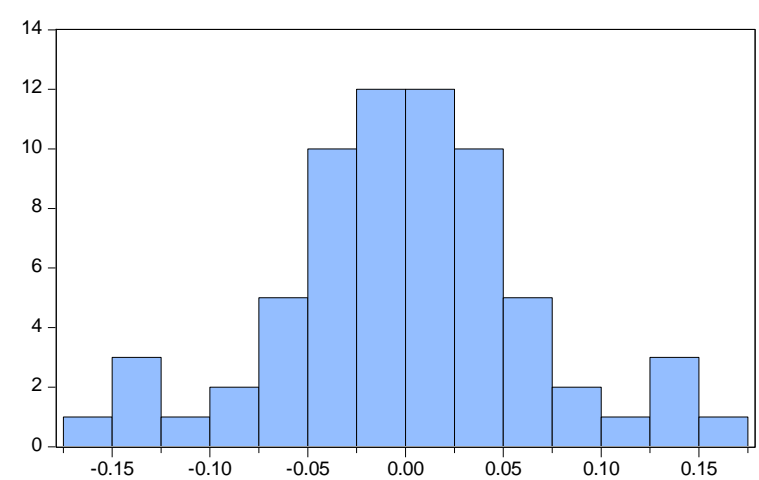

Figure 2. Normality Test

Source: Output Eviews 9 \begin{tabular}{|ll|}
\hline \multicolumn{2}{|l|}{ Series: Standardized Residuals } \\
Sample 2017 2018 \\
Observations & 102 \\
& \\
Mean & $1.31 \mathrm{e}-13$ \\
Median & $1.70 \mathrm{e}-07$ \\
Maximum & 0.155333 \\
Minimum & -0.155334 \\
Std. Dev. & 0.066425 \\
Skewness & $-6.42 \mathrm{e}-06$ \\
Kurtosis & 3.205242 \\
& \\
Jarque-Bera & 0.119352 \\
Probability & 0.942070 \\
\hline
\end{tabular}

Based on Figure 2 above, it shows that the Jarque-Bera probability value of 0.942 is greater than the 0.05 probability value, it can be concluded that the regression model is normally distributed, where the residual data distribution forms a normal distribution curve.

Table 5. Multicollinearity Test

\begin{tabular}{|c|c|}
\hline Variable & Centered VIF \\
\hline CR & 1.103854 \\
\hline DER & 1.204514 \\
\hline ROA & 1.126454 \\
\hline
\end{tabular}

Source: Output of Eviews 9

From Table 5 above, it seems that the grade of centered variance inflation factors (VIF) shows that grade of each variable is not more than 10 or $<10$. Therefore, it can be concluded that there is no multicollinearity between the independent variables in the regression model.

Table 6. Heteroscedasticity Test

\begin{tabular}{|c|c|}
\hline Variable & Value \\
\hline Obs*R-squared & $1.868<7.815$ \\
\hline Prob. Chi-Square & $0.6001>0.05$ \\
\hline
\end{tabular}

Source: Output of Eviews 9

From Table 6 above, it seems that the Obs * R-squared grade is 1.868 , while the chi-square table value at an error level of 5\% (0.05) and degree of freedom 3 is obtained by a value of 7.815 . When viewed from the Obs*R-squared value, it shows that the value is less than the chi-square table value $(1.868<7.815)$. Meanwhile, if you look at the chi-square probability value, which is 0.6001 , it shows a value greater than 0.05 , it can be concluded that there are no symptoms of heteroscedasticity in the regression model.

Table 7. Autocorrelation Test

\begin{tabular}{|c|c|c|}
\hline Variable & Criteria & Value \\
\hline Durbin-Watson stat & $\mathrm{du}<\mathrm{d}<4-\mathrm{du}$ & $1.738<1.814<2.262$ \\
\hline
\end{tabular}

Source: Output of Eviews 9

From Table 7 above, it seems that the Durbin-Watson grade is 1.814 . This value is going to be compared with the DW table with the number of observations $(n)=102$, the number of independent variables $(k)=3$, and a significance level of 0.05 where $\mathrm{dl}=1.617$ and the grade of $\mathrm{du}=1.738$. Because the grade of DW $=1.814$ is above the grade of $\mathrm{du}=1.738$ but below the value of $4-\mathrm{du}=2.262$, namely 
$(1.738<1.814<2.262)$, because DW is among the grade of du and $4-d u(d u<d<4-d u)$, then the hypothesis which states there is no positive and negative autocorrelation in a regression model cannot be rejected.

Table 8. Panel Data Regression

Random Effect Model

\begin{tabular}{|c|c|}
\hline Variable & Coefficient \\
\hline C & -0.178223 \\
\hline CR & 0.000461 \\
\hline DER & -0.254229 \\
\hline ROA & 0.147502 \\
\hline
\end{tabular}

Source: Output of Eviews 9

Table 8 above shows that the regression equation model formed based on the results of the studies is as follows:

$$
Y=-0.178223+0.000461 X_{1}-0.254229 X_{2}+0.147502 X_{3}
$$

From the above equation, it can be explained that:

1. If the constant grade is -0.178223 , it means if the independent variables, which are CR, DER, and ROA, are considered constant (worth 0), then the dependent variable, which is DPR variable will be worth -0.178223 . This means, when there is no change in the value of the CR, DER, and ROA, the DPR will not change.

2. If the regression coefficient value of the CR variable shows 0.000461 , it means if the CR variable has increased by (one) unit, while other independent variables, which are DER and ROA variables are considered constant (value 0), then dependent variable, which is DPR variable, will increase by 0.000461 . A positive sign on the regression coefficient value shows that CR has a positive influence on the DPR. This means the higher CR, the higher the DPR, and vice versa.

3. If the regression coefficient value of the DER variable shows -0.254229 , it means if the DER variables have increased by (one) unit, while other independent variables, which are CR and ROA, are considered constant (worth 0). ), the dependent variable, which is DPR variable, will decrease by -0.254229 . The negative sign on the regression coefficient value shows that DER has a negative effect on the DPR. This means the higher the DER, the lower the DPR, and vice versa.

4. If the regression coefficient value of ROA variable shows 0.147502 , it means if the ROA variables have increased by (one) unit, while other independent variables, namely CR and DER variables are considered constant (value 0 ), then dependent variable, namely DPR variable, will increase by 0.147502 . The positive sign on the regression coefficient value shows that ROA has a positive effect on DPR. This means the higher the ROA, the higher the DPR, and vice versa.

Table 9. Hypothesis Testing Partially

\begin{tabular}{|c|c|c|c|}
\hline Variable & t Value & Probability Value & Result \\
\hline CR & $0.015<1.984$ & $0.9880>0.05$ & $\mathrm{H}_{1}$ is rejected \\
\hline DER & $4.966>1.984$ & $0.0000<0.05$ & $\mathrm{H}_{2}$ is accepted \\
\hline ROA & $6.921>1.984$ & $0.0000<0.05$ & $\mathrm{H}_{3}$ is accepted \\
\hline
\end{tabular}

Source: Output of Eviews 9

Based on Table 9 above, it partially shows that CR has no effect on DPR variable, while the DER and ROA have an effect on DPR variable. 
Table 10. Simultaneous Hypothesis Testing

\begin{tabular}{|c|c|c|c|}
\hline Variable & F Value & Probability Value & Result \\
\hline$C R, D E R, \& R O A$ & $34.732>3.15$ & $0.0000<0.05$ & Accepted \\
\hline
\end{tabular}

Source: Output Eviews 9

Based on Table 10 above simultaneously shows that the CR, DER, and ROA have an effect on the DPR variable.

Table 11. Testing Coefficient of Determination

\begin{tabular}{|c|c|c|}
\hline Information & Value & Percentage \\
\hline R-squared & 0,515 & $51,5 \%$ \\
\hline
\end{tabular}

Source: Output of Eviews 9

From Table 11 above, it seems that variability of the dependent variable, which the DPR, can be explained by the independent variable, those are CR, DER, and ROA in this study amounted to $51.5 \%$, while the rest was $48.5 \%$ explained by other variables outside research model.

\section{Discussion}

The Influence of Current Ratio on Dividend Payout Ratio

The results showed that CR has an effect on DPR. Results of this study are also supported by the previous discussion which shows the $\mathrm{CR}$ is a ratio that quantifies the ability of companies to pay the short-term obligations whether debts that are due immediately while they are collected as a whole. Therefore, it indicates how many current assets are on hand to cover short-term liabilities that are due soon. CR is also can be considered a form of measuring the level of safety (margin of safety) of companies (Hery, 2018). Low CR means that the company lacks capital to pay off debt. However, if the measurement results of the CR are high, it is not necessarily that the company is in good condition either. The higher the CR, the more secure the company's debts to creditors. For creditors, the higher the CR the better, but for certain companies, it can mean different things. If this ratio is high, it means that the company has excessive current assets or something is not optimal (Ibrahim, 2019). The high CR shows that the high ability of companies to pay the short-term debt. The indicates that the availability of the company's current assets is high enough so that a company is able to pay dividends to shareholders. This means the higher the CR, the higher DPR. The results studies are supported by research conducted by Ibrahim (2019) and Adhyvian et al (2019) that the CR affects the DPR. While results of the study contradict by Purba et al (2019) and Sarmo et al (2019) that the CR has no effect on the DPR.

\section{The Influence of Debt to Equity Ratio on Dividend Payout Ratio}

Results showed that DER had an effect on DPR. Results of this study are also supported by the previous discussion which showed the DER is the ratio be used to quantify the proportion of debt to equity. DER is counted as the quotient among total debt and equity. DER is used to determine the ratio among the number of funds prepared by the creditor and the number of funds originating from the companies owners. Otherwise, DER attend to find out how much each rupiah of equity is used as debt collateral. The higher the DER, the smaller the owner's capital that can be used as debt collateral (Hery, 2018). If DER is higher, the risk faced by investors will be even greater. A high DER indicates that the company's dependence is also high. This is due to the large number of debt used by the companies to finance companies and the value of the existing debt will be borne by investors. Therefore, investors prefer companies that have a small DER, because the smaller the DER owned by the company, the less risk that will be borne by investors. Companies have a large DER grade, then the dividends distributed are getting smaller, this is because the profits generated by the company are used to pay debts that have been used by the company, and vice versa Adhyvian et al (2019). The high DER shows that the high debt the company has. This will have an impact on the ability of the company to pay the divide, it is assumed that the company is going to tend to cover the company's debt first. This means that the higher the DER, the lower the DPR. The results of this studies are espoused by Ibrahim (2019) and Mufidah 
(2018) that the DER affects the DPR. While the results of this study contradict by Purba et al (2019), Mufidah, and Khorunnisa (2016) that DER has no effect on the DPR.

\section{The Influence of Return on Assets on Dividend Payout Ratio}

ROA is a ratio that seems how big the ante of assets in making net income. Therefore, ROA is used to quantify how much net profit is going to be produced each rupiah of funds is inveterate total assets. ROA is counted by dividing net income to total assets. The higher ROA, the more increase the amount of net profit produced from each rupiah funds invested total assets. Otherwise, the lower ROA means lower the net profit produced from each rupiah of funds inveterate total assets (Hery, 2018). A positive ROA that seems of the total assets be used to operate, the firm can provide profits for the companies. Otherwise, if negative ROA that seems of the total assets be used, the firm gets a loss, and the greater the ratio the better because the company is considered capable of using its assets effectively to generate profits (Ibrahim, 2019). The high ROA shows the company's high capability to earn profits. The higher the profit the companies get, the higher dividends that will be distributed to shareholders. This means the higher the ROA, the higher DPR. The results of studies are supported by research conducted by Ibrahim (2019), Mufidah (2018), Mufidah, and Khorunnisa (2016) that ROA affected the DPR. Meanwhile, the results of this study contradict (Trilestari \& Kusuma, 2016). Last, ROA has no effect on the DPR.

\section{Conclusion}

From on the results of researches and discussion, the conclusion is as follow:

1. The results show that the CR affects the DPR. So the higher the CR, the higher the DPR. The reason is when CR is low, it can be considered that the company lacks capital to pay its debts. However, if the CR measurement results are high, it does not mean that the company is in good condition either. The higher the CR, the more secure the company's debts to creditors. For creditors, the higher the current ratio, the better, but for certain companies, it can mean different things. If this ratio is high, it means that the company has excessive current assets or something is not optimal. In other words, an increase in the liquidity position will also increase the dividend payments.

2. The results show that the DER affects the DPR. So the higher the DER, the lower the DPR. Therefore, investors prefer companies that have small DER value, because the smaller the DER value owned by the company, the less risk that will be borne by investors. Companies that have high DER value, means that the dividends distributed are getting smaller, this is because the profits generated by the company are used to pay debts that have been used by the company, and vice versa.

3. The results show that the ROA affects the DPR. So the higher the ROA, the higher the DPR. Positive ROA shows from the total assets used to operate, the company can provide profits for the company. Conversely, a negative ROA indicates from the total assets used, the companies get a loss, and the greater the ratio the better because the company is considered capable of using its assets effectively to generate profits.

\section{Limitations and Study Forward}

The research is limited to only a few factors, those are CR, DER, and ROA to the DPR. In addition, this research is only conducted on the mining company listed on the Stock Exchange for the period of 20162018.

\section{Acknowledgment}

The author would like to thank H. Niki Hadian, S.E., M.M., Ak., CA who initiated and provided input to the author in conducting this research. In addition, the authors would like to thank Universitas Widyatama Bandung for giving us a platform to explore our knowledge in the field of financial accounting. 


\section{References}

Adhyvian, R., Mardani, R. M., \& Wahono, B. (2019). Analisis Pengaruh Net Profit Margin (NPM), Current Ratio (CR) dan Debt to Equity Ratio (DER) Terhadap Dividend Payout Ratio. E-Jurnal Riset Manajemen.

Atmaja, L. S. (2008). Teori dan Praktik Manajemen Keuangan. Yogyakarta: 2008.

Brigham, F. E., \& Houston, F. J. (2011). Dasar-Dasar Manajemen Keuangan. Edisi 11. Buku 2. Jakarta: Salemba Empat.

Hery. (2018). Analisis Laporan Keuangan. Jakarta: Grasindo.

Ibrahim, M. (2019). Pengaruh Debt To Equity Ratio, Return On Asset, Current Ratio Terhadap Dividend Payout Ratio Pada Perusahaan Sub Sektor Farmasi. Jurnal Aplikasi Manajemen dan Inovasi Bisnis, 1 .

Ikatan Akuntansi Indonesia. 2018. Pernyataan Standar Akuntansi Keuangan. Edisi Revisi. Jakarat : Dewan Standar Akuntansi Keuangan.

Kasmir. (2019). Pengantar Manajemen Keuangan. Jakarta: Prenadamedia Group.

Mufidah dan Rikha Muftia Khorunnisa. 2016. Analisis Pengaruh Cash Ratio, Debt To Equity Ratio dan Return On Asset Terhadap Dividend Payout Ratio. Jurnal Fokus, Volume 6, Nomor 2 September 2016.

Mufidah, M. (2018). Pengaruh Asset Growth, Sales Growth, Net Profit Margin, Current Ratio dan Debt To Equity Ratio terhadap Dividend Payout Ratio Pada Perusahaan Yang Termasuk Dalam Indeks LQ 45 Tahun 2013-2016. J-MAS (JurnalManajemen Dan Sains), 3(1), 12.

Purba, D. P., Sheren, ., Valent, ., \& Angeline, . (2019). Pengaruh Current Ratio (CR), Debt To Equity Ratio (DER) dan Return on Equity (ROE) Terhadap Dividend Payout Ratio (DPR) Pada Perusahaan Sektor Industri Barang Konsumsi Di Bursa Efek Indonesia (BEI) Tahun 2013-2017. Going Concern : Jurnal Riset Akuntansi, 14(1), 214-224.

Samsul, M. (2015). Pasar Modal dan Manajemen Portofolio. Jakarta: Erlangga.

Sarmo, Sulaiman., Muttaqillah, dan Handri Amin Effendi. Pengaruh Earnings After Tax, Current Ratio, Debt To Equity Ratio Terhadap Deviden Payout Ratio. Universitas Mataram. Jurnal Ilmiah. Vol. 16 No. 1, Januari 2019: 86-98.

Sartono, R. A. (2001). Manajemen Keuangan. Yogyakarta: Fakultas ekonomi UGM.

Sjahrial, D. (2009). Pengantar Manajemen Keuangan. Jakarta: MItra Wacana Media.

Sutrisno. (2012). Manajemen Keuangan,Teori,Konsep, dan Aplikasi Edisi Kedelapan. Yogyakarta: Ekonisia.

Tandelilin, E. (2017). Pasar Modal. Yogyakarta: PT Kanisius Yogyakarta

Trilestari, A., \& Kusuma, D. R. (2016, Maret 1). Analisis Pengaruh Cash Positio, Debt To Equity Ratio, dan Return On Assets Terhadap Dividen Payout Ratio Pada Perusahaan-Perusahaan Yang Terdafatar Di Bursa Efek Indonesia Periode 2012-2014. Jurnal Fokus, 6(1).

Wicaksana, I. G. (2012). "Pengaruh Cash Rasio, Debt to Equity Ratio, dan Return On Asset terhadap Kebijakan Dividen pada perusahaan Manufaktur Di Bursa Efek Indonesia" Tesis. 